\title{
2016 Joint Policy Board of Mathematics Communications Awards
}

Two Communications Awards of the Joint Policy Board for Mathematics (JPBM) were presented at the Joint Mathematics Meetings in Seattle, Washington, in January 2016. The Museum of MATHEMAtics received the 2016 Communications Award for Public Outreach, and Simon SINGH was presented the 2016 JPBM Communications Award for Expository and Popular Books. The JPBM Communications Award is presented annually to reward and encourage journalists and other communicators who, on a sustained basis, bring mathematical ideas and information to nonmathematical audiences. JPBM represents the American Mathematical Society, the American Statistical Association, the Mathematical Association of America, and the Society for Industrial and Applied Mathematics. Each award carries a cash prize of US $\$ 1,000$.

Previous recipients of the JPBM Communications Award are:

- James Gleick (1988)

- Hugh Whitemore (1990)

- Ivars Peterson (1991)

- Joel Schneider (1993)

- Martin Gardner (1994)

- Gina Kolata (1996)

- Philip J. Davis (1997)

- Constance Reid (1998)

- Ian Stewart (1999)

- John Lynch and Simon Singh (special award, 1999)

- Sylvia Nasar (2000)

- Keith J. Devlin (2001)

- Claire and Helaman Ferguson (2002)

- Robert Osserman (2003)

- Barry Cipra (2005)

- Roger Penrose (2006)

For permission to reprint this article, please contact: reprint-permission@ams.org.

DOI: http://dx.doi.org/10.1090/noti1368
- Steven H. Strogatz (2007)

- Carl Bialik (2008)

- George Csicsery (2009)

- Marcus du Sautoy (2010)

- Nicolas Falacci and Cheryl Heuton (2011)

- Dana Mackenzie (2012)

- John Allen Paulos (2013)

- Danica McKellar (2014)

- Nate Silver (2015)

\section{Citation: MoMath}

The 2016 JPBM Communications Award for Public Outreach is presented to the Museum of Mathematics, "MoMath", for its innovative approach to presenting fundamental mathematical ideas to the public in a variety of creative, informative, and entertaining exhibits and events that engage audiences with the beauty and utility of mathematics in daily life.

\section{Biographical Sketch of MoMath}

To a mathematician, math is a world of discovery and exploration. It's a place where one can wonder "what if" and then seek the answers. It's a world of color, imagination, and beauty, a place where one can be creative and discover a host of unexpected connections to the world around us. But this place, this idea of math as an unbounded realm yet to be fully explored, is foreign to many people. Mathematics is often portrayed as a tool; a series of steps one performs to solve a particular problem. And those problems may have nothing to do with the world around us, or with the human experience.

The National Museum of Mathematics was founded to share the real world of mathematics with the public and to allow everyone to experience the sense of the wonder and beauty that can be found within this world. For more than seven years, the Museum has been working to create a sense of community, to bring together seasoned professionals with bright young students, academic mathematicians with their counterparts in education, senior citizens with wide-eyed toddlers, and people from all walks of life and all 


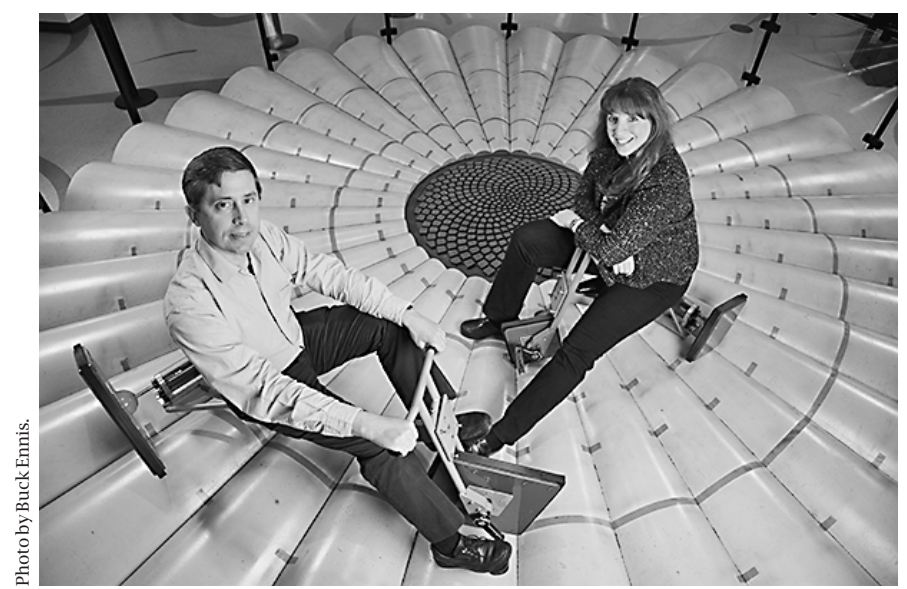

Glen Whitney, MoMath Treasurer, and Cindy Lawrence, MoMath Executive Director and CEO.

backgrounds, sharing together a unique experience as they view the world around them through a new, mathematical lens.

\section{Response from the Museum of Mathematics}

It is with great honor and appreciation that the National Museum of Mathematics accepts the 2016 Communications Award for Public Outreach of the Joint Policy Board for Mathematics. Since its inception, MoMath has been warmly welcomed by the mathematical societies and indeed by the entire mathematical community. Your members have provided support, encouragement, ideas, and feedback, and the Museum simply would not exist today and would not continue to flourish without the continued involvement and collaboration of each of your organizations and its members. It is our sincere hope that together we will continue to foster a greater understanding of mathematics and to provide a place that encourages one to step into this exciting world.

\section{Citation: Singh}

The 2016 JPBM Communications Award for Expository and Popular Books is presented to Simon Singh for his fascinating books on mathematical topics, including Fermat's Enigma, The Code Book, and The Simpsons and Their Mathematical Secrets, which have opened up the beauty of mathematics and mathematical thinking to broad audiences with clear and charming prose.

\section{Biographical Sketch of Singh}

Simon Singh is a writer and broadcaster who lives in London. Having completed his $\mathrm{PhD}$ in particle physics at the University of Cambridge and CERN, Singh joined the BBC's Science Department in 1990. He was a producer and director on programs such as Tomorrow's World, Horizon, and Earth Story. His documentary about Fermat's Last Theorem was titled "The Proof" in North America and broadcast as part of the Nova series on PBS. The film was nominated for an Emmy and won a British Academy of Film and Television Arts (BAFTA) award.

In 1997 he wrote a book on the same subject, titled Fermat's Last Theorem in the United Kingdom and Fermat's Enigma in North America, which was the first mathematics book to become a number one bestseller in Britain. It has been translated into over twenty-five languages.
Singh published The Code Book, a history of codes and codebreaking, in 1999. His most recent book is The Simpsons and Their Mathematical Secrets, which explores the numerous references to mathematics hidden in the world's most successful TV show. The references are the result of a writing team that contains several people with strong mathematical backgrounds. His other books are Big Bang, a history of cosmology, and Trick or Treatment? Alternative Medicine on Trial, coauthored with Edzard Ernst.

He has presented several radio and TV shows in the United Kingdom, most notably The Science of Secrecy (a five-part history of cryptography), Mind Games (a puzzle series), and Five Numbers, Another Five Numbers, and $A$ Further Five Numbers.

His mathematical activities on stage have included Theatre of Science (which he performed with Richard Wiseman in London, Edinburgh, Dublin, and New York) and The Uncaged Monkeys (a show involving comedians and nerds, which played to forty thousand people across twenty-three shows in the United Kingdom). Online, he is a contributor to Brady Haran's very successful YouTube channel "Numberphile".

He has spoken to approximately five hundred school groups over the last twenty-five years, and his schoolbased projects include the Undergraduate Ambassadors Scheme, which currently runs in over one hundred STEM departments in the United Kingdom, sending one thousand undergraduates into schools each year in order to support pupils.

\section{Response from Simon Singh}

I am delighted to receive this award, particularly as my background is in physics rather than mathematics.

Although I am very proud of my books and my other work, I am sometimes concerned that we place too much emphasis on popularizers such as myself while paying insufficient attention to what happens in high schools. And when we do look at the achievements of schools,

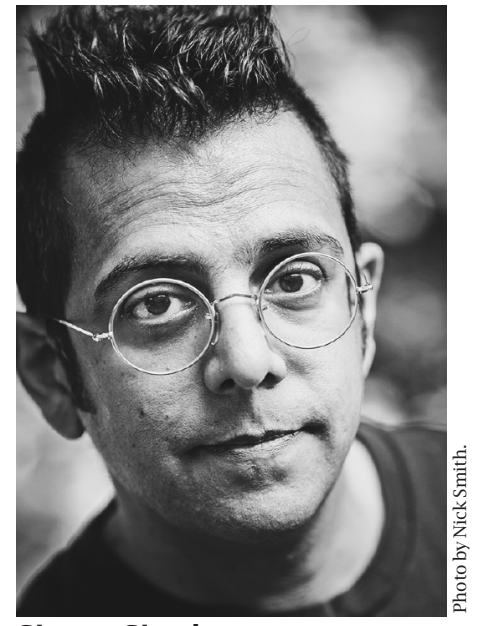

Simon Singh my experience is that we tend to focus on supporting and encouraging the weak or average students, while perhaps ignoring the strong students.

While many keen, strong young mathematicians will read popular books on mathematics, they are not a replacement for a rich and challenging curriculum, presented day after day, year and year, something that will provide a springboard for the mathematicians (and scientists and engineers) of tomorrow. 